\title{
Preface to the special issue
}

Preface to the special issue

Since first established in 1990, Hong Kong Public Administration Association (HKPAA) is committed to promote and enhance the quality of research and practice of public sector management in Hong Kong and the region. It provides a forum for the identification and discussion of important issues in public policies and management. We have collaborated with local universities as well as overseas counterpart organizations to arouse keen interest in the pursuit of best practices in public services through regular dinner talks, seminars and conferences by renowned leaders in both public and private organizations.

A new website for the Association has been launched in 2020 to mark the $30^{\text {th }}$ Anniversary of HKPAA. It features new icons on speeches of top leaders given at our luncheons, dinners and conferences; full PDF versions of all issues of the PAP journal as well as photo albums of all our activities.

To celebrate the $30^{\text {th }}$ Anniversary of HKPAA and the $20^{\text {th }}$ Anniversary of the School of Professional Education and Executive Development (SPEED) of The Hong Kong Polytechnic University, we have organized an International Conference on Developments and Trends on Public Administration into the Third Decade of the $21^{\text {st }}$ Century in 2020 at the HK PolyU. Papers presented at the conference will be considered for a special issue for the PAP Journal in 2021.

Public Administration and Policy - An Asia-Pacific Journal (PAP) was first launched in 1992 and jointly published by HKPAA and City University of Hong Kong. It was suspended in 2005 due to the departure of the Editor-in-Chief. In spring 2012, it was re-launched with the support of the new co-publisher, the SPEED, HK PolyU and a new Editor-in-Chief. The PAP Journal has progressed smoothly from print version to e-version and now online, in the past nine years. We have published general issues on various aspects of public administration, one special issue on "Health Policies" and two on "Tertiary Education".

We are delighted to have a successful collaboration partnership with Emerald Publishing Limited in the United Kingdom. Since 2018, PAP has been published online in open access on the Emerald Insight Platform. In order to have the journal indexed in ESCI and SCOPUS as soon as possible, PAP will move forward to publish three issues with at least one special issue per year starting from 2020.

In this special issue on "Corruption scandals in six Asian countries", we are delighted to have a world renowned academic and expert in anti-corruption, Professor Jon S.T. Quah from Singapore as the guest editor. With his expertise and networking, all the papers are very well written by specialists in the field. We hope this special issue will make significant contributions to the understanding and prevention of corruption scandals for policy makers, scholars and students in various countries around the world.

\author{
Peter K.W. Fong \\ Editor-in-Chief, PAP Journal \\ President, Hong Kong Public Administration Association
}

(C) Peter K.W. Fong. Published in Public Administration and Policy. Published by Emerald Publishing Limited. This article is published under the Creative Commons Attribution (CC BY 4.0) licence. Anyone may reproduce, distribute, translate and create derivative works of this article (for both commercial and non-commercial purposes), subject to full attribution to the original publication and authors. The full terms of this licence may be seen at http://creativecommons.org/licences/by/4.0/legalcode

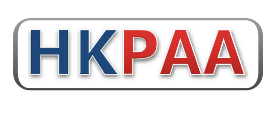

(3)


PAP

23,1

4

\section{About the Editor-in-Chief}

Professor Peter K.W. Fong, PhD (New York University), is President of Hong Kong Public Administration Association and Editor-in-Chief of PAP Journal; and Managing Director of Peter Fong \& Associates Ltd. He teaches Strategic Management and supervises DBA students' dissertations of the University of Wales Trinity Saint David. He also holds advisory and visiting Professorships in several Mainland China universities, namely Tsinghua, Renmin, Tongji, and Tianjin Universities. He is a member of Hong Kong Institute of Planners, Planning Institute Australia, and Chartered Institute of Logistic and Transport. He was formerly a Teaching Fellow, Judge Business School, University of Cambridge; Director of EMBA programme, HKU Business School; Associate Professor, Department of Urban Planning \& Urban Design, HKU; Executive Vice President \& Professor, City University of Macao (formerly AIOU); Head, Centre for Executive Development, HKU SPACE; Honorary Professor, China Training Centre for Senior Civil Servants of Ministry of Human Resource \& Social Security, PRC; Studies Director, Civil Service Training \& Development Institute of the HKSAR Government; Visiting Scholar, MIT; and Consultants, World Bank and Delta Asia Bank in Macao. Peter K.W. Fong can be contacted at: fongpeter@netvigator.com 